\title{
Reflections on the Green Economy (Redemption of the Principles of Mill and Pigou): A View of a Brazilian Environmentalist
}

\author{
João Batista Drummond Câmara \\ Centro Universitário de Brasília, UniCeub/ICPD, Brasília, Brazil \\ Email: joaocamara2012@bol.com.br
}

Received 11 April 2014; revised 8 May 2014; accepted 1 June 2014

Copyright (C) 2014 by author and Scientific Research Publishing Inc. This work is licensed under the Creative Commons Attribution International License (CC BY). http://creativecommons.org/licenses/by/4.0/

(c) () D Den Access

\section{Abstract}

The current context of global efforts in the pursuit of sustainable development can be characterized by the perception of the scientific-technological losses of ecosystems and ecosystem services and their consequences for the survival of humanity in the face of threats of imbalances in the basic conditions for survival such as food production, the environmental quality, natural control of pests and diseases, loses of biodiversity and climate changes. Some recent initiatives at global, regional and local level are pointed and some conceptual trends and deployment strategies advance towards the consolidation of the principles of sustainable development, despite several difficulties for effectively reaching its goals. The trend of gradual changes in the models of developing nations and in the patterns of production and consumption is portrayed objectively, seeking to correlate with principles of environmental economics and green economy, since Cecil Pigou and Stuart Mill principles to recent researches as Kenneth Boulding, Herman Daly, Nicholas Georgescu-Rogen, Franz Capra, Ignacy Sachs, Edgar Morin, beyond others. The ability of the United Nations and governments to intervene in neoliberal logic aiming wider benefit to society and the reduction of the negative effects of market distortions, as striking on the global stage, represents a true redemption of the principles advocated by Cecil Pigou, at the beginning of the last century, both for the global economy and for their effects on environmental and social conflicts, social exclusion resulting from the current economic systems which are not necessary new strategies, principles, or economic formulas, but decision making to tackle the market with seriousness to promote equity, social justice and environmental sustainability, without sacrificing progress and development, as evident in the current discussion of social inclusion and the convergence of individual and collective interests, so far in the development model based on increasing production and consumption, yet with little environmental responsibility. 


\section{Keywords}

\section{Principles of Environmental Economics, Green Economy, Sustainable Development, Productions and Consumption Patterns, Environmental Services, Anthropogenic Footprint}

\section{Context for the Adoption of the Principles of Sustainable Development through the Adoption of Actions to Strengthen the Green Economy}

The report of the Millennium Ecosystem Assessment (MEA) defined environmental service (or ecosystem) as "the benefits people obtain from ecosystems" and which can be analyzed under the following main aspects or categories: provisioning services such as food, water, wood, regulating services, such as those that affect climate, floods, disease and water quality, cultural services linked to recreational benefits, aesthetic and spiritual, and support services, which include soil formation, photosynthesis and nutrient recycling (Millennium Ecosystem Assessment, 2005) [1].

But significant changes in ecosystem services are occurring due to anthropogenic processes due to the expansion of the agricultural frontier, deforestation, urban sprawl, mining activities, increase of services such as energy, transport, communication and tourism, and pollution of soil, water and the air. According to the report of the MEA, about $60 \%$ of these services are degraded or used unsustainably, which increases the likelihood of accelerated change, abrupt and irreversible, with significant consequences for human welfare, and threaten the survival of many communities, especially in developing countries (Millennium Ecosystem Assessment, 2005) [1]

In September 2000, 189 nations signed commitment to fight extreme poverty and other societal ills. The result materialized into eight Millennium Development Goals (MDGs) to be achieved by 2015 (Millennium Declaration), which are: poverty reduction, universal primary education, gender equality and empower women; reducing child mortality, improving maternal health, combating HIV/AIDS, malaria and other diseases, ensuring environmental sustainability and the establishment of a global partnership for development. In September 2010, the nations renewed their commitment to accelerate progress towards the achievement of these goals (UNDP, 2012) [2].

According to Martini and Ribeiro (2011) [3] from the mid 18th century humans have altered the natural landscape directly in $40 \%$ to $50 \%$ of its full and brands which influence affect more than $83 \%$ of the land surface, called "anthropogenic footprint". The sediment transport due to human actions is now ten times greater than the natural and the cause is the erosion of land due to agriculture, construction, and indirectly, the damming and diversion of rivers. The total biomass of humans reaches 40 million tons of carbon (C) and it is eight times higher than that of wild terrestrial vertebrates, which is 5 million tons. Already biomass of marine vertebrates (50 million tons) is still greater than the human, but only equivalent to half of the biomass of animals domesticated by mankind, which includes different types of creations like oxen, horses, goats, sheep, chickens and other.

According to Brown (2001) [4] there is a tendency for the demand of the global economy, which is growing and poorly structured, lower the productivity on the planet, because ecosystems are being destroyed completely due to the pressure for increased production that generates capital and economic advantages.

The report Global Environment Outlook-5 (GEO-5) prepared by the United Nations Environment Programme (UNEP), based on the analysis of data and indicators from several collaborating institutions, shows an environmental destruction framework of the "unprecedented" due to rapid population growth coupled with the unbridled consumption (UNEP, 2012) [5]. According to the report, from ninety of the environmental goals and objectives at global level only four of them (which means that only $4 \%$ of the total) obtained some progress. GEO- 5 is a warning - the world was not able to achieve the Millennium Development Goals in relation to biodiversity conservation, despite progress achieved to eliminate the production and use of substances harmful to the ozone layer (CFCs), lead (tetraethyl) the composition of gasoline, the search for alternative sources of energy and encouraging research aimed at reducing pollution.

In relation to the Brazilian environment, the report refers to the process of "savannization" of the Amazon rainforest, with estimates that logging at $40 \%$ of its area or the increase in global temperature $4^{\circ} \mathrm{C}$ means its possible extinction. Considering the annual rates of deforestation in the Amazon, according to IBAMA (2012) [6], 
in the period 1988-2011, between $7000 \mathrm{~km}^{2}$ and $29,000 \mathrm{~km}^{2}$ were deforested, representing $0.3 \%$ to $0.5 \%$ per year, totaling almost $16 \%$ in 2012 or $3 \%$ of the total deforested area.

The forecast is that by 2060 the emissions of greenhouse gases will be double what it is today, increasing global temperature $3^{\circ} \mathrm{C}$ or more by the end of the century, providing significant losses in agriculture and extreme damage in weather events, with reflected in the reduction of global GDP due to rising health care costs. The region of the planet with greater contribution of greenhouse gas emissions will be the Asia-Pacific region, with about $45 \%$ of global $\mathrm{CO}_{2}$ emissions related to energy by 2030 and $60 \%$ of global emissions by 2100 (UNEP, 2012) [5]. This region is also considered to be in serious endangered condition, with about $20 \%$ of its vertebrate species at risk of extinction, as well as the corals, which were reduced by $38 \%$ since 1980 .

Over 600 million people are also at risk and should be without access to safe drinking water by 2015 and 2.5 billion do not have access to basic sanitation. Since 2000, groundwater reservoirs have been damaged while world over the past 50 years has tripled. The report also identified the West Asia as a region of great concern, because of the scarcity of water. Even with the growing demand, renewable water resources per capita in the region will decrease by more than half by 2025, suggesting that more desalination plants will be needed, despite the high energy consumption.

China, India and South Korea, three of the fastest economically growing countries, are developing renewable energy projects and energy efficiency, and made voluntary commitments to reduce their emissions.

Despite the advanced loss of environmental resources and ecosystem services and the reduction of the environmental quality were recorded some significant progress, according to the GEO-5, in relation to the environment, such as reducing the production and use of chemicals destroy the ozone layer, the removal of lead from fuel, increasing access to improved water sources and further research to reduce pollution of the marine environment.

The reduction of health risks achieved by phasing out lead-based fuels has economic benefits estimated at US\$ 2.45 trillion per year, or approximately $4 \%$ of global GDP. This advance will prevent the emergence of millions of cases of skin cancer by 2050 and million cases of cataracts by 2100 (UNEP, 2012) [5].

The scope of the 40 environmental goals set by the UN, through the UNEP (2012) [5] shows little progress in some, such as the increase of protected areas and reducing deforestation, which fell from 16 million hectares per year in the 1990s to 13 million in 2000-2010; the promotion of policies to reduce Amazon destruction in Latin America; improvement in Colombia public transportation systems that help reduce emissions of greenhouse effect, thus decreasing the contribution to climate change.

Several global, regional and local lawsuits, are being sought to face losses and environmental consequences, most evident in climate change in the genetic erosion, reducing the amount and quality of available freshwater, degradation and loss of soil productivity. Population growth and development of some economies, such as China, "systems are pushing the limits of the environment destabilizing", punctuates the document, which also notes that the current consumption patterns, especially in the West, are unsustainable (Redação Eco, 2012) [7].

The green economy is the guideline for the transition from linear economy (not sustainable) for circular economy (sustainable), and requires a radical change in patterns of production and consumption, causing the transformations imposed on ecosystems and ecosystem services, which already show for the formation of a new geological era called Antropocene ${ }^{1}$ by British and Australian scientists at the conference Planet under Pressure, held in London in 2012, whose main brand was to analyze the transforming capacity and degrading humanity. This new era will succeed current period defined by science as Holocene.

The growth of human influence on the environment was recognized in 1873 by the Italian geologist Antonio Stoppani (1824-1891), who said there is a "new telluric force whose power and universality may be compared to the larger forces of the Earth", baptizing this period as Antropozoico (Martini \& Ribeiro, 2011) [3]. Another geologist, the American Joseph Le Conte (1823-1901), suggested the name Psicozoic, in 1879, the book Elements of Geology. In 1926, the French anthropologist and Jesuit Teilhard de Chardin (1881-1955) and the Russian geochemist Vladimir Vernadsky (1863-1945) called this period of development of the Earth as "noosphere" (the world of thought), during which the intellectual power human generated effects sufficient to be considered as a geological force (Martini \& Ribeiro, 2011) [3].

Anthony Giddens, English political scientist known for his holistic view of society, described the Anthropocene as a "runaway world" in which the human being triggered processes more powerful than their attempts to

\footnotetext{
${ }^{1}$ Although this term is not to be consecrated by science and therefore be open to criticism, it was decided to include it because it was highlighted during the discussions at the United Nations Conference on Sustainable Development (Rio + 20).
} 
control it. This term was popularized in 2000 by chemist Paul Crutzen [8], who won the Nobel Prize in Chemistry in 1995 and since then it has been increasingly accepted in scientific circles as unofficial designation. The term Anthropocene is being analyzed to designate a new geological period and its recognition can be formalized by the International Commission on Stratigraphy 2016.

Likewise, is becoming increasingly apparent revision of the name of the human species, Homo sapiens or Homo economicus (economic man) ${ }^{2}$, which describes man as a rational, perfectly informed and self-centered, a being who wants wealth, avoids unnecessary work and has the ability to decide to achieve their goals (Zabieglik, 2002) [9].

The shift to a new paradigm of civilization, required for sustainability has to be developed on a sustainable basis and involves a thorough review of values, principles, ethics and review rescue needs of every citizen in a world of finite resources, exhaustible and up unrecoverable, resuming a speech known but not yet assimilated or practiced, to fit the individual needs in the limits of resources and environmental services.

According Balmford et al. (2002) [10] the human nature gets the aesthetic and cultural benefits of climate regulation, soil formation, nutrient cycling power, direct collection of native species to obtain food, fuel, fiber and medicine products, etc. The authors attribute the degradation of the unknown nature of the economic benefits of conservation, the lack of information on the cost-benefit ratio (1:100), the lack of mechanisms for compensation for the losses in the short term/opportunity cost subsidies and incentives of governments to promote deforestation (US\$ 950 billion per year), the lack of investment in conservation land and sea (US\$ 6.5 billion per year, and half in the USA), and to achieve a minimum conservation would take US\$ 45 billion per year, i.e., only $5 \%$ of the subsidies used to promote environmental degradation.

According to Pavese (2011) [11] the gradual increase of environmental awareness in the business sector takes place under pressure from the world market, the globalization of the economy and society about the environmental impacts and the quality of products and services. In this sense, international commitments being entered into by the United Nations to adapt production for sustainable development (e.g. Basel Convention, Rotterdam Convention, Vienna Convention, Montreal Protocol, Kyoto Protocol, etc.). Also according Pavese (2011) [11] is necessary to seek evidence about the risks and social and economic costs generated by current patterns of overuse of natural resources, as well as highlight the opportunities of a transition to more sustainable practices. UNEP launched in 2008, the Green Economy Initiative (Green Economy Initiative-GEI) aimed at supporting the development of a comprehensive plan to transition to a green economy dominated by investment and consumption of goods and promoting environmental services (UNEP, 2011) [12].

Although there was still a concept dedicated to the green economy, it can be said that it is "one that results in improved human well-being and social equity, while significantly reducing environmental risks and ecological scarcities”. The green economy is based on three main strategies: reducing carbon emissions, increased energy efficiency and use of resources, and preventing the loss of biodiversity and ecosystem services (Pavese, 2011: p. 16) [11].

According to UNEP (2010) [13] the ability to balance an investment with its return will be key to the emergence of a green economy. Approaches are based on sustainable finance and responsible investment are adopted and integrated into financial institutions and capital markets to greening of economic sectors will include more than 2 billion people at the "bottom of the pyramid". The evaluation, integration and good management of ecosystems and biodiversity that sustain global economic and social activities, need to be an integral part of financial services in order to achieve complete transformation to a green economy (UNEP, 2010) [13].

According to the document Green Economy: synthesis for policy makers, prepared by UNEP in 2011, the green economy can also be defined as the one that results in improved human well-being and social equity, while significantly reduces environmental risks and ecological scarcities. It is a low-carbon economy, efficient use of resources and socially inclusive.

In traditional economic system, current costs with the external economy, or externalities, were not evaluated, fixed or recorded and that such externalities are not fully internalized, because of the omission of issues ESG3, which makes the investment policies and decision-making processes of the major investment institutions. The companies listed in this document, 3000 were analyzed and generated environmental costs of US\$ 2.2 trillion

\footnotetext{
${ }^{2}$ The term economic man emerged from the economic theories of the nineteenth and early twentieth century and has been increasingly used by countless experiences coming from the field of social psychology, which shows that the behavior of Homo sapiens diverge significantly predicted by the assumptions of an economic man (Zabieglik, 2002) [9].
} 
annually. Companiesindex All Countries World Index (ACWI) ${ }^{3}$ are associated with more than US\$ 1 trillion in costs with environmental externalities, annually.

The incorporation of $\mathrm{ESG}^{4}$ in the investment portfolios of pension funds (US\$ 29.5 trillion), equity markets (US\$ 34 trillion) public and private debt (US\$ 77 trillion), net (US\$ 32.8 trillion) sovereign wealth funds (US\$ 2 - 3 billion), reserve funds (US\$ 1.5 trillion) and private equity (US\$ 1.3 trillion) between companies sectors and regions, will allow control of costs incurred by environmental and social externalities. Over 700 institutional investors representing nearly US\$ 20 trillion in assets were invested in responsible investment (United Nations Principles of Responsible Investing PRI), and an indication of the direction of capital to activities with low carbon and resource efficient future (UNEP, 2010) [13].

According to UNEP (2010) [13] provide good advice and support to governments, companies and civil society is essential to achieve the transition to a green economy and part of the Green Economy Initiative. Accordingly, UNEP advances with national green economy through technical advisory services that include assisting the development and evaluation of reforms, analytical support and research, based on international experience and best practices, as well as in analytic capabilities, particularly in developing countries. In providing such services, UNEP works in partnership with other UN agencies, and a network of research institutions, major policies to generate timely data. These services are responses to specific requests of the pioneers, who consider the green reforms in their economies.

According to Young (2011) [14] the increasing dependence on exports based on natural resources or pollution-intensive goods, is a structural problem in Latin American countries, which have their exports increasingly concentrated in natural resources or industrial goods characterized by a relatively high degree of pollution in their production processes. Also according to Young (2011) [14] it is the result of deindustrialization and shows that the process of liberalization initiated in the 1990s, along with the boom in commodity prices, in 2000, left a structural change in the region, returning to a position in which the dynamism of foreign markets is based on direct sales of natural resources or of goods whose production is intensive in emissions. Combining both results, in 2000 the exports of Brazil and Latin America have become increasingly dependent on spurious competitiveness, depleting natural resources, rather than a virtuous cycle in which the gains from trade are obtained from the technical and innovation.

Consumers in developed countries are increasingly aware of the environmental footprint of the products they consume and the position of Latin America can be seen as weak if this awareness reflected in trade restrictions against products harmful to the environment. Despite these problems, it is common to find defenders of the current growth trend grounded in natural resources, arguing that environmental losses are a necessary cost of economic development. This hypothesis, usually called "environmental Kuznets curve", explains that in certain stages of development the sacrifice of natural resources is inevitable to improve the living conditions of the population.

According to Gaetani et al. (2011) [15] to know the situation of Brazil towards a green economy and its prospects, the following questions are crucial: what are the main achievements in relation to the green economy? How is Brazil situated in relation to other countries? What are the main challenges? These are broad questions, and closely related to contemporary discussions about the impacts of climate change and new formulations of economic theory. Also according Gaetani (2011) [15] Brazil is now internationally recognized as a leading environmental dialogues with rich countries, developing, emerging and poor countries in relation to the environmental agenda. On the occasion of the major world conferences, in the sphere of international technical cooperation and South-South platforms (IBSA, BASIC, BRICS, UNASUR, etc.), It was expected to become increasingly a position of leadership and vanguard this country but is important remember what such leadership requires.

Sustainable development includes fundamentally social equity, ecological prudence and economic efficiency (Sachs, 1993) [16], which are the foundation for a green economy. The definition of sustainable development, as Pearce and Turner (1991) [17], means maximizing the net benefits of economic development subject to maintaining the services and quality of natural resources over time. According to Common (2005) [18], the essential features of sustainable development for society need three ecological imperatives:

- The size of the population on the planet should be relatively stable (or declining);

${ }^{3}$ The ACWI is developed and maintained by Morgan Stanley Capital International (MSCI), a provider of decision support tools to investment clients, such as pension plans major funds.

${ }^{4}$ Governance Environmental, Social and Corporate (Environmental, Social and Corporate Governance (ESG), describes the three main areas of concern that have developed as key factors to measure the sustainability and impact of investment in a company or business. ESG is the generic term used as a socially responsible investment (UNEP, 2005) [19]. 
- Global population and its activities shall not exceed the limits of natural resources imposed by the biosphere (capacity);

- The organization of society and the economic system should be such that human health and quality of life, and high rates of employment, does not depend on increased levels of consumption and products from natural resources or activities that reduce ecosystem productivity.

\section{Contemporary Concepts and Principles of Economists of the 18th and 19th Centuries and Its Application in the Green Economy}

To achieve these requirements, there must be a structural change in the economy and society, implying the following rules: the use of renewable resources with lower or equal to the natural rate of regeneration; optimizing efficient use of nonrenewable resources subject to replacement by new technologies.

According to Adam Smith (1723-1790) the father of the theory of economic liberalism, the pursuit of self-interest is the driving force of the collective welfare and social harmony appears as the work of the invisible hand of the market, which operates the mediation of natural individual interests with collective interests. In his work, Smith defends the efficiency of state and institutions as regulators of the market, giving the market the ability to exploit the natural resources that are available to everyone equally. In practice, what we have shown is the unequal access to resources, creating striking differences between rich and poor, and between developed and developing nations.

The first school of economic thought, phisiocracy, was created by the French physician Francois Quesnay, when he formulated the principles of utilitarian social philosophy (get maximum satisfaction with minimum effort) in 1758, with the publication of his Economic Framework.

Quesnay argued that agriculture realized the source of all wealth, giving the sense of "power of the earth" to the concept of phisiocracy. The Physiocrats were the first economists to realize that the production of goods was a real possibility of enrichment of human societies since remained in tune with the natural dynamics of ecosystems. For them, the nature deserves the attention and care of society, precisely because it is essential. For Vivien (2000) [20] the Physiocrats saw in nature idyllic character, being precursors of the first demonstrations for better use of natural resources. It can be said that although agriculture is an important source of wealth, Quesnay did not realize the potential of the fledgling industry of the time and its use as a tool for achieving wealth industrialized countries, mainly from the industrial revolution, enabling industrialized countries as guides of world economic development.

In the late eighteenth century, classical economists inaugurated the era of the finite world. The theory of demographic dynamics of Malthus and Ricardo of diminishing returns suggest that the limits of natural resources means failure in the supply of good quality land. Thus, as the population grows and, concomitantly, it needs more food available, the trend is to incorporate less fertile land.

John Stuart Mill, in his Principles of Political Economy, praised the steady state of the economy as "socially desirable in the long term", to allow society to cast off the "bandage materials" and was devoted to the activity "of living" in interlacing pacific "with nature". Mill argues that the accumulation of capital at any price and population growth prevented the assertion of other core values such as autonomy in the sphere of work, respect for nature and the aesthetic and moral improvement (GIANNETTI, 1993: p. 44) [21].

The principle of harmony of interests, advocated by Adam Smith, can be widely questioned, since the notorious concentration of wealth existing in England at the time showed that the satisfaction of individual interests did not necessarily correspond to the satisfaction of the general interest. Mill wanted the individual to coincide well with the collective good, but no shocks, which would be dominant in the moral and altruistic. In his book Utilitarianism, Chapter II, Stuart Mill emphasizes the pursuit of happiness in the principle of utility, saying that (Mill, 1983) [22]:

Happiness understood as pleasure and no pain. [...] Pleasure and freedom from pain are the only things desirable as ends [...] is for the pleasure inherent in them, either as a means of promotion of pleasure and pain prevention.

Stuart Mill can be considered an author of transition between the old economic thinking (with an emphasis on aspects related to production of wealth) and modern economic thought (which emphasizes aspects of the distribution of wealth). The author states that the social problem of the future will gather more individual freedom of action with the common ownership of raw materials of the globe and equal participation of all work associated 
with the (Instituto Liberal, 2013) [23].

\section{The Question of Altruism in the Context of Sustainability}

The question of altruism in the context of sustainability has been taken up in various ways such as Edgar Morin, French sociologist, president of the Institut International de Recherche Politique of Civilisation (IIRPC), to deliver the lecture "La tierreestinquiet" during the Rio + 20, in June 2011, the eradication of poverty through the redemption of a value that needs to be awakened in humans - solidarity. For this, there must be, on the one hand, solidarity among nations, and on the other, encouraging the creation of what he calls direct democracy through the creation of regional forums composed of various actors and legitimate.

Poverty eradication is shown, according to Morin, a major challenge to achieve sustainable development, reaffirming that you can not isolate the ecological question of the social question, since poverty is a global problem. You need to adopt policies to combat social exclusion and achieve integrated and solidarity of nations that focus on financial speculation to the detriment of the primary function of the State, which is to ensure the basic rights of the population, which, according to Morin, requires greater participation and full citizenship. Also according to Morin, the green economy can solve social inequalities by providing clean energy, favoring small farmers and agriculture decreasing damage to protect biodiversity and promoting social inclusion, generating work.

For Morin, participation in decision-making nations should adopt models of education to teach children to be more understanding of others and understand the meaning of the value of knowledge to address issues imposed. Children and young people need to think about what it means to be human in the context of his time, so that they are able to think about solutions to the challenges ahead.

The environmental depletion generated from the expansion of productive activities put in doubt by the end of the twentieth century, the optimism of the liberal belief in the development of all nations in the post World War II, from the finding of infeasibility environmental increased levels of production and consumption in developed countries. With this, Illich (2000) [24] draws attention to what he considers to be a condemnation of almost half the world's population to live "forever" with the ills of poverty and hunger. Foladori (1999) [25] meanwhile adds that there is concrete evidence that there is no possibility of revising the social injustices nor wear while environmental relations are governed by the free market economy.

\section{The Economics of Welfare}

Arthur Cecil Pigou, English economist from Cambridge University and a student of Alfred Marshall, described the concept of externalities in 1912 (Wealth and Wealth Fare, 1912) [26] and in 1920 with the book The economics of welfare, broke with the tradition of neoclassical economics to advocating the replacement of private industrial action by the State, by pointing a fee as a measure of the state to influence the behavior of economic agents in the market, aiming at the correction of negative externalities.

Pigou assumed that all unintended effects of productive activities, both individual and corporate, are called externalities (the more usual negative when damaging or positive, even if rare, when benefit) and described the effect which explains the increase of demand for consumer goods in a period of deflation, and this economic logic guiding currently the major economies of the early 21st century. The optimistic view, Pigou believed in the power of rational analysis, in progress and ability to well-wishers to make significant reforms in economic systems, for improvements to society. Based on Pigou (1912) [26], Edward H. J. N. Dalton established the principle of "Pigou-Dalton", which proves that a transfer of an individual's income for richer to poorer, provided that reverse social position between the two, resulting in greater social equality (Dalton: p. 351) ${ }^{5}$ [27].

Positive externalities do not cause problems, because there's only benefit. As for the conflicts which cause negative theory Pareto seeks to solve, namely that the use of a resource by one of the players involved necessarily adversely affecting other (Mankiw, 1999) [28].

Government intervention would propose Pigouvian taxes. These should correspond to a value that reflects the social cost to the community infringed wear caused by the use of natural resources by a single agent. This principle called "Polluter Pays Principle", by means of tax collection, incorporates the external effects caused to the environment. On this principle, enterprises can embed in their product prices the environmental depletion caused by production activities, incorporating environmental costs into the final price to the consumer, there is no reason, therefore, to let corporate polluters to pollute (Vivien, 2000) [20].

The discussion on the limits of economic development and the consequences for the environment and society

\footnotetext{
${ }^{5}$ Also known as the Baron Hugh Dalton or Dalton.
} 
have been treated by several authors, notably: Garret Hardin (1968) [29], with the Tragedy of the Commons and concern of a "finite world needs to endless"; Marshall with the analysis of the benefits and individual welfare; Constanza and Daily, World Bank, with bases for environmental accountability, David Pearce with Environment Economics, where losses are replaced by technology; Von Berthalanfy and their contribution to the Systems Theory, Adam Smith in the Wealth of Nations - usefulness of the goods and the purchasing power of the market, David Ricardo with the return value and Marshall with his postulate that the price tends to value the extent of the shortage.

Paul Samuelson, internationally renowned economist, analyzes the use of nature as a mere externality, as the use of natural resources of the planet by the system of capitalist production of goods, in the words of Samuelson, is full of "neighborhood effects". To control these effects it is necessary to establish institutional decrees fixing areas of public control of the use of these resources. The completeness of natural forms distorted land tenure, wastes, pollution of water resources, among others, lead to Samuelson, some special problems of economic analysis (Samuelson, 1972) [30]. These problems are amenable to correction via appropriate use of the price system.

Authors of most contemporary economics have not evolved much in dealing with the environmental issue, like Mankiw (1999) [28], which dealt with natural resources as "some important common features", and proposed regulations and/or taxes to reduce negative externalities.

\section{From the Limits of Growth to Rio + 20: Global Policies for Sustainable Development}

In the report Limits to Growth, published in 1968, called the Club of Rome predicted so pessimistic that by the year 2000 would be virtually exhausted the reserves of fossil fuels, oil and coal, specifically, making it virtually impossible to maintain the current modern economies.

The finding of this report is that the pace of global economic growth is sustained in a progressive, insatiable, perverse exploitation of natural resources and, consequently, the conditions of human survival. Some significant experiences in the valuation of environmental damage to the application of penalties and requiring repair of environmental damage such as: IcmesaSeveso, Italy (in a defoliants factory explosion), Exxon Valdez oil spill in Alaska; Bhopal/India—Explosion in agrochemical factory of Union Carbide in 1984; Love Canal in Niagara Falls and Hooker Chemicals, 1978; leaks oil from Petrobras in Brazil, Duque de Caxias refinery (Guanabara Bay/RJ) and Araucaria Refinery in Pinhais/PR), both in 2000.

In the 1970s, the thinker Ignacy Sachs, the School of High Studies in Social Sciences (EHESS), Paris, proposed a "greening" of the system of wealth production, the so-called eco-development, which could happen through a strategy that seeks to combine the need for economic development with the rational use of environmental resources, especially through the use of alternative energy more efficient and less polluting, specifically solar and wind.

In 1987 came the controversial concept of sustainable development, with the publication of the Brundtland Report (1986), which defines sustainable development as "one that meets current needs without sacrificing the ability of society to meet their future". The concept of sustainable development emerges in this context as a conciliatoryproposition, recognizing that technical progress relativizes environmental limits of ecosystems and proposes that the use of these change to be rationally sustainable, admitting, however, that economic growth is necessary but not sufficient to eliminate poverty and reduce social inequalities.

From this period, some actions that strengthened environmental protection worldwide were multilateral environmental agreements (Convention for the Resources of the Sea-MARPOL, Basel Convention, Montreal Protocol, Kyoto Protocol, Convention on Biological Diversity, among others); labeling systems and environmental certification (Blue Angel, BS, ISO 14000, FSC, etc.); environmental commodities ${ }^{6}$; responsible action (1992),

\footnotetext{
${ }^{6}$ The term Environmental Commodities is roughly defined as "tradable goods globally homogeneous standardizable, easily sortable and arranged in units of appropriate measures, subject of maintenance, over time, their qualities/characteristics unique, subject to certain market supply and demand, subject to appropriate pricing, as well as related to the scope of natural resources such as water, electricity, among others” (Ribas, 2001) [34]. In June 1999, the Inventory of Economic Resources of the Atlantic, coordinated by the National Council of the Biosphere Reserve of the Atlantic, brought to light a research that identified products with environmental characteristics and high social value-orchids, bromeliads, herb mate, tree fern, palm, medicinal plants, etc. Caixetas. Whose marketing required a new financial market (Matias \& Freitas, 2003) [35]. Then comes the proposal of the Brazilian Commodities Exchange Environment (BECE) or Brazilian Commodities Exchange Environmental, economists and environmentalists a transdisciplinary team called CTAs who longed to build a financial mechanism attest, protect and stimulate sustainable development. The proposal was inspired by the BECE Veiling Holambra (SP), bag flower communityDutch, beyond the experience of the project coordinator, the economist Amyra El Khalili, who was the mentor of Project Cereals Exchange Sao Paulo (ASCB) and consultant of the Commodities and Futures Exchange (Matias \& Freitas, 2003) [35].
} 
Agenda 21 (1992), in Brazil Law 9605/1998-environmental Crimes; Law 9966/2000—Oil and Gas Law (2000), Law 9985/2000—Protect Areas National System), Law 12305/2010—National Policy on Solid Waste, among others.

Over time, natural resources were included in the representations of the production function, but keeping the multiplicative form , which means the perfect substitutability between capital, labor and natural resources, and therefore the assumption that the limits imposed by availability of natural resources can be indefinitely overcome by technological progress that substitutes capital (or labor). In other words, the economic system is seen as large enough so that the availability of natural resources becomes a constraint to expansion [...] (Romeiro, 2003: p. 7) [31].

Ronald Coase, Nobel Prize winner in economics in 1991 for his studies on transaction costs and property rights for the structure and systemic functioning of the economy, suggested in 1960 that the rights issue of externalities can be coherently defined. For him, there would be no transaction costs between the parties if it were left to them the power to negotiate. In other words, the free negotiation between two agents who "dispute" the same natural resource leads to an optimal level of emission of externalities (Mankiw, 1999) [28]. Thus, Coase showed that taxes and subsidies are not necessary if the people affected by the externality or the people who create them can meet and negotiate, seeking mutual benefits. However, most economists today still defend Pigouvian taxes as a much more efficient way to deal with pollution.

Ecological economics has, as main feature, the character trans-interdisciplinary and maybe that's why in today's economics textbooks have no reference to that area. This new branch of economics emerged between the years 1970 and 1980. The need to study the relationship between natural ecosystems and the economic system was observed both in the western/Capitalist as the eastern side/Communist which, despite different ideologies, sat in the same industrial process, the Taylorism (Foladori, 1999) [25].

The introduction of new technologies in production processes expresses the "common good" and a more equitable distribution of development benefits, in addition to being seen as a solution to the ecological crisis. This assumes neutrality of scientific and technical progress and the possibility of all societies reach the final stage of development and modernity.

In view of the paradigm shift of Capra, Sousa Santos, Sachs, Morin and others economic linear to circular economy or unsustainable to sustainable development, the authors point to a deep reflection and critical crises generated by current models of development: globalization of the economy, population explosion: the failure of hegemonic models of development: environmental degradation and the social disruption; ecological and socioeconomic contradictions and adverse effects on the environment and humanity.

The work of Kenneth Boulding (The Economics of the Coming Spaceship Earth, 1966), Herman Daly (On Economics as a Life Science, 1968) and Nicholas Georgescu-Rogen (The Entropy Law and the Economic Process, 1971) [32] were also significant contributions to the historical construction of this new vision of economic development, seen as a precursor of the so called "greening" of economics. These authors, even with different theoretical arguments converge on the need to incorporate the ecological balance and dynamics of ecosystem services in economic analysis, arguing that the system of exchange of goods and social life point to a necessary revision of the criteria for analysis and evaluation of economic policies, based exclusively on the economy, which should incorporate the ecosystem imbalances and integrations (Rocha, 2002) [33].

With the realization that the approaches of economics can not explain the trajectory of environmental depletion, economists subdivided into three groups:

- Environmental economics based on neoclassical economics and focusing its analysis on the scarcity/abundance of resources;

- Ecological economics, which attempts to incorporate aspects of biogeochemical cycles and energy exchanges in the thermodynamic analysis of environmental depletion;

- Marxist economics, which sees environmental issues as another contradiction of the capitalist system and thus understands that the value of natural resources is given by the social relationship between humans (Rocha, 2002) [33].

Regardless of the philosophical and conceptual dichotomies exist with regard to economic thought and its impact on economic development, should seek greater efficiency in the use of natural resources, reducing and/or eliminating pollution, stabilizing the levels of consumption of natural resources per capita and obeying the limits of the carrying capacity of the planet.

For this, ecological economists propose economic policies that, in short, has the purpose of guiding the most 
efficient use of environmental resources; replace non-renewable resources by renewable resources and reduce polluting processes that alter the biogeochemical cycles of many ecosystems.

According to Cavalcanti (1996) [36], an economic process is truly sustainable when three basic environmental functions are not disregarded:

- Provision of resources;

- Absorption and neutralization of waste from economic activity;

- Maintaining the supply of environmental services provided conditions amenity provided by the Green functions such as climate stability.

Determine the economic value of an environmental resource is to estimate the monetary value relative to other goods and services available in the economy (Motta, 1998) [37]. When the costs of degradation are not paid by those who generate these costs are externalities for the economic system, meaning costs that affect others without due compensation. Economic activities are planned without considering environmental externalities and hence the consumption patterns of people are forgotten with no internalization of environmental costs.

Although environmental resources have not recognized its price in the market, its economic value exists insofar as its use alters the level of production and consumption (welfare) of society. Despite government intervention to be legitimate, it is not simple because there can be problems of consensus as low budgetary provisions in view of the high costs of management; policies inducing environmental losses and equity issues that hinder the fulfillment of the law.

Government intervention may also include separate instruments, such as the determination of property rights, the use of norms or standards, economic instruments and monetary compensation for damages to others. Therefore, the introduction of economic criteria in environmental management is essential. If the economic system exceed the carrying capacity of ecosystems, the processes sustaining life on the planet can break. Thus, an alternative is to incorporate environmental destruction (externalities) in the prices of products and services.

According Acselrad (1995) [38], there are two types of difficulty regarding the internalization of environmental costs: difficulties apparently "technical" to value ecological processes uncertain and heterogeneous, and difficulties in identifying the sources to support the economic values of such processes and enforce decision mechanisms or market. The importance of environmental valuation systems not only from the need to scale environmental impacts, internalizing them to the economy, but also to highlight the costs and benefits resulting from the expansion of human activity.

This value can be interpreted in various ways. For Pearce and Turner (1991) there are three possibilities to embed environmental values, which are adopted by the politics and ethics of industrialized societies:

- Values expressed via individual preferences (set and measured in terms of willingness to pay and be compensated);

- Public preference values (standards imposed by collective pressure, through laws and regulations);

- Ecosystem values physical-functional (non-preferred, measured in natural sciences).

Internalize environmental costs in the production process, so that each activity has its impacts properly accounted for, is an excellent tool to improve the allocation of economic resources, but it is a process that basically depends on the identification of environmental impacts and their correct economic valuation (Mattos, Mattos, \& Filho, 2002) [39].

A macroeconomic perspective, the price of scarce raw materials, pollution and deposition does not reflect its true value and costs to society (Kraemer, 2005) [40]. According to this author, the health risks and remediation of contaminated sites environmental costs are not usually borne by the polluter, but by the general public. Environmental costs include both the costs and the internal and external refer to all costs related to safeguard and environmental degradation. The costs of environmental protection include prevention, disposal, planning, control, alteration and repair of environmental damage and human health, related companies, governments or persons (Kraemer, 2005) [40].

Government's role is to apply policy instruments such as environmental taxes and regulations control emissions and waste, in order to reinforce the "polluter pays" and integrate external costs in the company's calculations. What are the environmental costs of the company? What first comes to mind are the costs related to the treatment of contaminated sites with technologies to control of effluents and waste disposal.

Have been widely recognized the limits of traditional accounting methods and financial analytics, to reflect the organizations' efforts toward sustainability and provide managers with the information needed for making sustainable business decisions. To some extent, information about the environmental performance of organiza- 
tions may be available, but the companies as well as public authorities, those who decide are rarely able to relate environmental information to economic variables and missing them, especially information about environmental costs.

Set the environmental component of these costs is often difficult to measure and value, as well as cleaner technologies, which are in many ways more efficient to prevent emissions and waste at source, as well as many other costs, including increased efficiency or aspects of health and safety.

The component "environment" is hardly separable. Ultimately, if a solution is $100 \%$ focused on the environment is not in reality, because, in general, is a treatment solution for end of line, that does not solve the problem at source, transferring it to other environmental category (for example air to soil and soil to water). These solutions have costs that are not accounted for.

\section{Green Economy as a Global Goal: Rio + 20 and Beyond}

The term green economy has become the most discussed in recent years and especially since its inclusion as a central focus of the World Conference on Sustainable Development, Rio + 20, which has not reached a consensus on this concept. During the event, the less developed nations have expressed their fear that the establishment of a green economy would make the marketing of their products due to lack of technology or enhancement of competitiveness of products on the new requirements. On this subject, Morales cites Fidel Castro as a wise commander of revolutionary Cuba, who said: "stamp out hunger, not the man. Let's pay the environmental debt, not the debt” (Gomide, 2012) [41].

According to the BID/MMA (2012) [42], the green economy should be seen as:

$\ldots$ an adaptive process... which requires the creation of mechanisms, policies, legal and institutional frameworks to coordinate and integrate the economic, social and environmental. In this context, one of the ways and measures to be taken would be the development of a national strategy, the institutionalization of the strategy process, the creation of legal mechanisms and appropriate performance and mobilization, involvement and institutional strengthening for engaging national a continuous process (BID/MMA, 2012: p. 57) [42].

The theme of common but differentiated-principle of Rio - 92, under which developed countries must pay more than the others - it was one of the issues of greatest tension at Rio +20 . On the one hand the developed countries argue that in today's world that no longer applies, on the other, developing countries continue to require help to eradicate poverty (Gomide, 2012) [41].

The social and popular movements (women, indigenous, blacks, youths, farmers, families, peasants, workers, peoples and traditional communities, maroon, fighters right to the city and religions around the world), trade unions and civil society organizations to different countries attending the people's Summit, Rio +20 , focused their interventions and contributions in debates and forums of various social and environmental justice, aiming to build convergences and alternatives to the relationship between humans and nature, assuming the urgent challenge to stop the new phase of restoration of capitalism and to build new paradigms of society.

According to the guidelines developed by the organizers of Rio +20 , this means judging the welfare and human development so that it is not simply measuring GDP. It also means creating business models that incorporate the value of ecosystem services in support of, such as pollination of crops and water purification and air services that are not normally considered in GDP, but suffer pressure from economic growth (Powell, 2012) [43].

For 20 years, the Global Forum, held in Flamengo Beach in Rio de Janeiro city, denounced the risks that humanity and nature ran with privatization and neoliberalism and, despite the effort, the People's Summit considered to have been significant setbacks in relation to human rights already recognized, therefore, as this crisis deepens, more corporations move against the people's rights, democracy and the nature, sequestering the common property of mankind to save the economic-financial system.

Capitalism, in the view of the conclusion of the People's Summit, leads to loss of social control, democratic and community on natural resources and strategic services, which continue to be privatized, turning rights into commodities and limiting the access of people and goods services necessary for survival. He points to the green economy as:

One of the expressions of the current phase of financial capitalism which also makes use of old and new 
mechanisms, such as the deepening debt public-private, the overstimulation consumption, ownership and concentration of new technologies, carbon markets and biodiversity, grabbing and foreign ownership of land and public-private partnerships, among others (Declaration of the Peoples Summit Rio + 20).

As pointed solutions for coping with the current ecological crisis, the Summit offers a defense of public spaces in cities with democratic governance and popular participation; cooperative and solidarity economy, food sovereignty, a new paradigm of production, distribution and consumption, and the change energy matrix, which are examples of real alternatives in the current agro/urban/ industrial market policies. They are also claimed to broaden the concept of work, the recognition of women's work and a balance between production and reproduction. Were also claimed the freedom to organize and the right to collective bargaining, as well as the establishment of a broad network of social welfare and protection, understood as a human right, as well as public policies that guarantee decent working conditions prioritizing youth.

A system of global environmental governance would benefit if there was greater participation of NGOs in policy mechanisms, thus contributing to reverse the current situation of limited participation of NGOs in UN programs, while seeking legitimacy for its policies by involving the civil society. According to Gemmill and Bamidele-Izu (2005: p. 113) [44], creativity, flexibility, entrepreneurial nature and the ability of perception and conception of long-term, often distinguish NGOs from government agencies.

According to the BID/MMA (2012) [42], the process of implementation of a national strategy for the green economy should consider:

... nationally the participatory process also implies the involvement of governmental and non-governmental spheres, adopting appropriate roles, including design strategies, exchange of information, decision making, implementation, among others. Thus, an effective green economy initiatives in Brazil, within the context of sustainable development and poverty eradication, requires that it be participatory, practical and reflective (BID/MMA, 2012: p. 57) [42].

The strengthening of diverse local economies and territorial rights, will build community economies stronger. These savings provide sustainable livelihoods and community solidarity, which are vital components of ecosystem resilience. The diversity of nature associated with cultural diversity is the foundation for a new paradigm of society.

The social transformation necessary for achieving sustainability requires convergence of actions, joints and agendas from the resistance and counter-hegemonic alternative to the capitalist system that is in place in all corners of the planet. Social processes accumulated by organizations and social movements that converged at the People's Summit pointed to the following axes of struggle:

- Against militarization of states and territories;

- Against the criminalization of social movements and organizations;

- Violence against women;

- Against large corporations;

- Against the imposition of unjust economic debt payments;

- The guarantee of the right of peoples to land and urban and rural territory;

- Food sovereignty and healthy food against pesticides and GMOs;

- For warranty and achievement of rights;

- Solidarity to the peoples and countries, especially those threatened by military coups or institutional, as is happening now in Paraguay;

- The sovereignty of the people in control of the commons against the attempts of commodification;

- The democratization of the media;

- The recognition of the historical social and ecological debt.

The implementation of the green economy requires the use of various tools, including the regulatory, economic and fiscal investments in green infrastructure, financial incentives, reform of subsidies, public procurement and sustainable green procurement, information disclosure for sustainability, partnerships, volunteers mechanisms of social participation for the construction and redesign of public policy and economic development plans, transparency in public service, improvement of social control mechanisms in government actions, among others.

The GEO-5 (UNEP, 2012) [5] points out that there is a need for clear goals, long-term, sustainable develop- 
ment, and more responsibility on the part of countries with international agreements.

According to the GEO-5 goals with specific and measurable goals were more successful with the bans on substances that deplete ozone and lead in petrol. The report instructs that it is crucial for governments to add value to natural resources such as mangroves, rivers and forests, and include it in the national accounts. Advancement in fulfilling and strengthening measures, including environmental courts, it is also necessary, as well as management of marine pollution, more samples for pollution data and better tools for water management (UNEP, 2012) [5]. These questions relate to the process of critical review of global environmental governance.

The world population growth and the consequent development of some economies promoted the meeting of some countries to form a group called BRICs (Brazil, Russia, India, China and South Africa). These countries are pushing environmental systems to destabilizing limits, according to the GEO-5. The document also stresses that current consumption patterns, especially in the West, are unsustainable, as the following excerpt.

Governments are habitually afraid of committing to targets and achieving results, although they can not deny that both steps are necessary for good governance. To avoid the issue in Johannesburg and Rio de Janeiro, only need look at the experience of the last ten years to see the prospects for the next decade: more futile discussions and inconclusive, more sterile political debates about who is not fulfilling its obligations and more investments lost nationally and internationally. Continue in blind flight (Hale \& Prescott-Allen, 2005: p. 62) [45].

Based on the results achieved at Rio +20 and considering the reflections prior to the conference, recommended by Hales and Prescott-Allen (2005) [45], we believe that the positions of the UN member states, event participants, demonstrated the difficulties in finding consensus on global environmental goals and the assumption of formal commitments to effect sustainable development efforts and strengthen the green economy.

The Rio + 20 World Summit left as a result the statement “The Future We Want" as the final document of the event, whose content has several principles, strategies and actions for a transition towards a green economy that promotes poverty reduction and preservation of environment. President Dilma Rousseff announce the achievements of Rio +20 , the official closing ceremony, said that the final document goes far in relation to the Earth Summit 1992, and Johannesburg, 2002, and shows the design shared sustainable development by stating:

... that the foundations were laid for an agenda for the twenty-first century. Brought poverty eradication to the center of the debate of the future we want, and create the Sustainable Development Goals, to focus and guide our goals (Agência Efe, 2012) [46].

Other highlights in this regard were the signature of 692 voluntary commitments from UN agencies, governments, NGOs, companies and universities, with an expected investment of up to US\$ 513 billion dollars in associations, programs and actions to the next 10 years, in areas such as transport, energy, green economy, disaster reduction and environmental protection, desertification and climate change (Agência Efe, 2012) [46].

Other measures announced by the President was the provision by Brazil of financial resources by US\$ 6 million to fund the UNEP, for developing countries, and \$ 10 million (ten million dollars) to address climate change affecting the most vulnerable countries and small islands. Such measures, although timid to face the challenges of sustainability, shown as demonstration effect to UN member countries (Agência Efe, 2012) [46].

According to the BID/MMA (2012) [42], to implement and succeed in the green economy initiatives in the country, it's necessary to get dedication and commitment at the federal, state and municipal (local) levels, with effective involvement and close dialogue between the different regional levels, as well as between different sectors of producers and consumers and different social stakeholders.

\section{Conclusions}

The ability of the government to intervene in neoliberal logic aiming at wider benefit to society and the reduction of the negative effects of market distortions, as striking on the global stage, represents a true redemption of the principles advocated by Pigou, at the beginning of the last century, showing more once again, both for the global economy and for their effects on environmental and social conflicts, that social exclusions resulting from the current economic systems are not necessary new strategies, principles, or economic formulas, but decision making to tackle the market with seriousness to promote equity, social justice and environmental sustainability, without sacrificing progress and development.

You can also reaffirm Mill on the need of a detachment from material life and a search for a lifestyle more immaterial and in harmony with nature, with the need to establish effective systems of control of population 
growth and increased relevance of moral values, unselfish and aesthetic, facing a harmony of interests, as evident in the current discussion of social inclusion and the convergence of individual and collective interests, so far in the development model based on increasing production and consumption, yet with little environmental responsibility. This seems to be the keynote of the current global environmental debate and puts Mill in line with the sustainable development discourse, or rather, the sustainability of economic development.

According to ecologist Erle Ellis, mankind has the following choice: runing a good Anthropocene or facing a series of crises. The choice depends on the actions taken going forward by states, international institutions and national society, governments and the private sector, because the outcomes of the Rio +20 were not encouraging as the actual process of civilizational transition, required for reverse the environmental degradation and threats to the survival of humanity.

Lastly, considering what has been previously exposed and targeting challenges to the necessary changing patterns of production and consumption current to a more sustainable basis, we recall the words of the Brazilian song named Sun of Spring, performed by Brazilian musicians Ronaldo Bastos and Beto Guedes: "The lesson we know by mind, now we can only learn it”, or else one of the famous phrases of the Brazilian writer Millor Fernandes in his book named "Reflections Without Pain” “... I saw this movie, and I die in the end!” (Fernandes, 1977) [47].

\section{References}

[1] Millennium Ecosystem Assessment (2005) Ecosystems and Human Well-Being: Synthesis. Island Press, Washington, DC, 1.

[2] UNDP (2012) Declaração do Milênio. http://www.pnud.org.br/ODM.aspx

[3] Martini, B. and Ribeiro, C.G. (2011) Antropoceno: A época da humanidade? Ciência Hoje, nº 283, 39.

[4] Brown, L. (2001) Eco-Economy. Worldwatch Institute, Washington.

[5] UNEP (2012) Global Environment Outlook 5. UNEP.

[6] BAMA (2012) Taxa de desmatamento anual na Amazônia. http://www.ibama.gov.br

[7] Redação ECO (2012) Menos de 1\% das metas ambientais globais tiveram avanço significativo, aponta GEO-5. http://www.ecodesenvolvimento.org/posts/2012/junho/menos-de-1-das-metas-ambientais-globais-tiveram

[8] Crutzen, P.J. and Stoermer, E.F. (2000) The “Anthropocene”. Global Change Newsletter, 41, 17.

[9] Zabieglik, S. (2002) The Origins of the Term Homo Oeconomicus. Gdansk, 123-130. http://cepa.newschool.edu/het/profiles/mill.ht

[10] Balmford, A., Bruner, A., Copper, P. and Costanza, R. (2002) Economic Reasons for Conserving Wild Nature. Science Compass Review, 297.

[11] Pavese, H.B. (2011) Delineamentos de uma economia verde. Conservation International, Política Ambiental, 8, 15-23.

[12] UNEP (2011) Towards a Green Economy: Pathways to Sustainable Development and Poverty Eradication. United Nations Environment Programme, Nairobi, 4.

[13] UNEP (2010) Green Economy Report: A Preview. UNEP DTIE, Switzerland, 25 p.

[14] Young, C.E.F. (2011) Potencial de crescimento da economia verde no Brasil. Política Ambiental, Conservation International, Belo Horizonte, 8, 88-97.

[15] Gaetani, F., Kuhn, E. and Rosenberg, R. (2011) O Brasil e a economia verde: Um panorama. Política Ambiental, Conservation International, $8,78$.

[16] Sachs, I. (1993) Estratégias de transição para o século XXI: Desenvolvimento e meio ambiente. Studio Nobel, São Paulo.

[17] Pearce, D.W. and Turner, R.K. (1991) Economics of Natural Resources and the Environment. The Johns Hopkins University Press, Baltimore.

[18] Common, M. and Stagl, S. (2005) Ecological Economics: An Introduction. Cambridge University Press, Cambridge. http://dx.doi.org/10.1017/CBO9780511805547

[19] UNEP (2005) A Legal Framework for the Integration of Environmental, Social and Governance Issues into Institutional Investment: A Report Produced for the Asset Management Working Group of the UNEP FI. Freshfields Bruckhaus Deringer. http://www.unepfi.org/fileadmin/documents/freshfields legal resp 20051123.pdf

[20] Vivien, F.D. (2000) Economía y Ecologia. Ediciones ABYA-YALA, Quito.

[21] Giannetti, E. (1993) Vícios Privados, Benefícios Públicos? Companhia das Letras, São Paulo. 
[22] Mill, J.S. (1983) Princípios de economia política: Com algumas de suas aplicações à filosofia social (2 volumes). Introdução de W. J. Ashley; apresentação de Raul Ekerman; tradução de Luiz João Baraúna. Abril Cultural, São Paulo. (Os Economistas).

[23] Instituto Liberal (2013) Galeria dos Autores Liberais: John Stuart Mill: 1806-1873. http://www.institutoliberal.org.br/biblioteca/galeria-de-autores/john-stuart-mill/

[24] Illich, I. (2000) Necessidades. Dicionário do desenvolvimento. Guiapara o conhecimentocomopoder. Vozes, Petrópolis, 155-172.

[25] Foladori, G. (1999) Los límites del desarrollo sustentable. Banda Oriental. RevistaTrabajo y Capital, Montevideo.

[26] Pigou, A.C. (1912) Wealth and Welfare. Macmillan and Co., London.

[27] Dalton, H. (1920) The Measurement of the Inequality of Incomes. Economic Journal, 30, 348-461. http://dx.doi.org/10.2307/2223525

[28] Mankiw, G. (1999) Introdução à Economia—Princípio de Micro e Macroeconomia. Campus, Rio de Janeiro.

[29] Hardin, G. (1968) The Tragedy of the Commons. Science, 162, 1243-1248. http://dx.doi.org/10.1126/science.162.3859.1243

[30] Samuelson, P.A. (1972) Maximum Principles in Analytical Economics. American Economic Review, 62, $249-262$.

[31] Romeiro, A.R. (2003) Economia ou Economia Política da Sustentabilidade.

[32] Georgescu-Roegen, N. (1971) The Entropy Law and the Economic Process. Harvard University Press, Cambridge. http://dx.doi.org/10.4159/harvard.9780674281653

[33] Rocha, J.M. (2002) As limitações disciplinares diante da problemática ambiental: Os novos pressupostos da ciência. Redes (Santa Cruz do Sul), 7, 35-50.

[34] Ribas, L.C. (2001) Commodities ambientais e sua relevância econômica. In: Weschenfelder, P.N., Org., Direito Ambiental, Editora Plenum, Caxias do Sul/RS.

http://www.mp.ba.gov.br/atuacao/ceama/material/doutrinas/esgotamento/commodities_ambientais_e_sua_relevancia_e conomica.pdf

[35] Matias, A.B. and Freitas, Z.C. (2003) Commodities ambientais: Uma análise acerca da comercialização em bolsa de valores no mercado financeiro brasileiro. Centro de Pesquisas em Finanças-CEPEFIN, Ribeirão Preto. http://cepefin.org.br/publicados_pdf/commodities_ambientais_bolsa_valores.pdf

[36] Cavalcanti, C. (1996) Condicionantes biofísicos da economia e suas implicações quanto à noção do desenvolvimento sustentável. In: Romeiro, A.R., et al., Eds., Economia do meio ambiente: Teoria, políticas e a gestão de espaços regionais, UNICAMP, Campinas, $377 \mathrm{p}$.

[37] Motta, R.S. (1998) Manual de Valoração Econômica dos Recursos Ambientais. Ministério do Meio Ambiente, dos Recursos Hídricos e da Amazônia Legal, Brasília, 218 p.

[38] Acselrad, H. (1995) Externalidade ambiental e sociabilidade capitalista. In: Cavalcanti, C., Ed., Desenvolvimento e natureza: Estudos para uma sociedade Sustentável, Cap. 7, Fundação Joaquim Nabuco, Cortez; Recife, São Paulo, 128-138.

[39] Mattos, K.M.C., Mattos, A. and Filho, N.J.F. (2000) Uma abordagem conceitual sobre a valoração econômica. http://www.cpap.embrapa.br/agencia/congresso/Socio/MATTOS-043.pdf

[40] Kraemer, M.E.P. (2005) A contabilidade medindo sua responsabilidade social. www.ambientebrasil.com.br/gestao/contabilidade.doc

[41] Gomide, R. (2012) Sul-americanos chamam economia verde de "novo capitalismo”: Presidente da Bolívia quer perdão de dívida externa. Rafael Correa, do Equador, pede “compensação, não caridade”. IG, Rio de Janeiro.

http://ultimosegundo.ig.com.br/ciencia/meioambiente/2012-06-21/sul-americanos-chamam-economia-verde-de-novo-c apitalismo.html

[42] BID/MMA (2012) Iniciativas de Economia Verde no Brasil: Experiências das esferas federativas em promover uma economia verde inclusiva. Banco Interamericano de Desenvolvimento-BID e Ministério do Meio Ambiente-MMA. BR-T1232, Brasília, Apoio ao Governo Brasileiro para preparação para a Rio + 20, 125 p.

[43] Powell, R. (2012) Cientistas anunciam início do Período Antropoceno. http://isebvmf.com.br/?r=noticias/view\&id=234093

[44] Bamidele-Izu, A. and Gemmill, B. (2005) O papel das ONGs e da sociedade civil na governança ambiental global. In: Esty, D.C. and Ivanova, M.H., Eds., Governança Ambiental Global: Opções \& oportunidades, SENAC, São Paulo, $301 \mathrm{p}$.

[45] Hale, D. and Prescott-Allen, R. (2005) Voo cego: Avaliação do progresso rumo à sustentabilidade. In: Esty, D.C. and Ivanova, M.H., Eds., Governança Ambiental Global: Opções \& oportunidades, SENAC, São Paulo, 301 p. 
[46] Agência EFE (2012) Dilma diz que Rio + 20 lançou bases de agenda para o século XXI.

http://veja.abril.com.br/noticia/internacional/dilma-diz-que-rio-20-lancou-bases-de-agenda-para-o-seculo-xxi

[47] Fernandes, M. (1977) Reflexões Sem Dor. Ed. Edibolso, São Paulo, 91 p. 
Scientific Research Publishing (SCIRP) is one of the largest Open Access journal publishers. It is currently publishing more than 200 open access, online, peer-reviewed journals covering a wide range of academic disciplines. SCIRP serves the worldwide academic communities and contributes to the progress and application of science with its publication.

Other selected journals from SCIRP are listed as below. Submit your manuscript to us via either submit@scirp.org or Online Submission Portal.
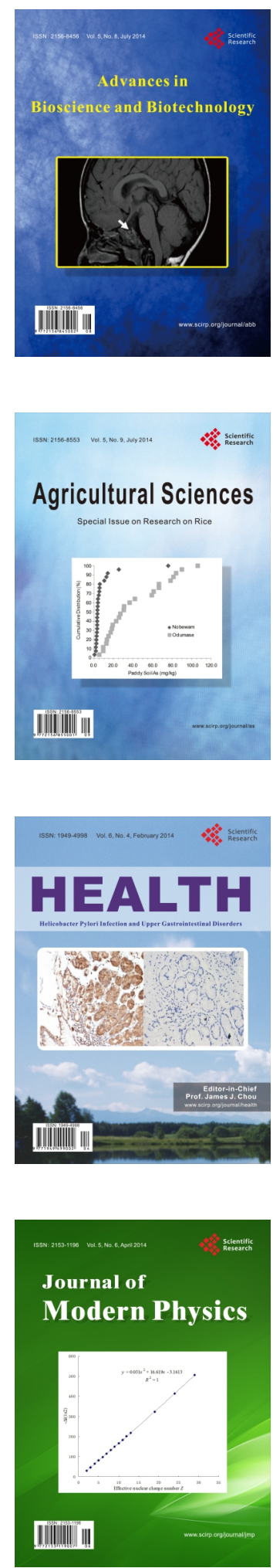
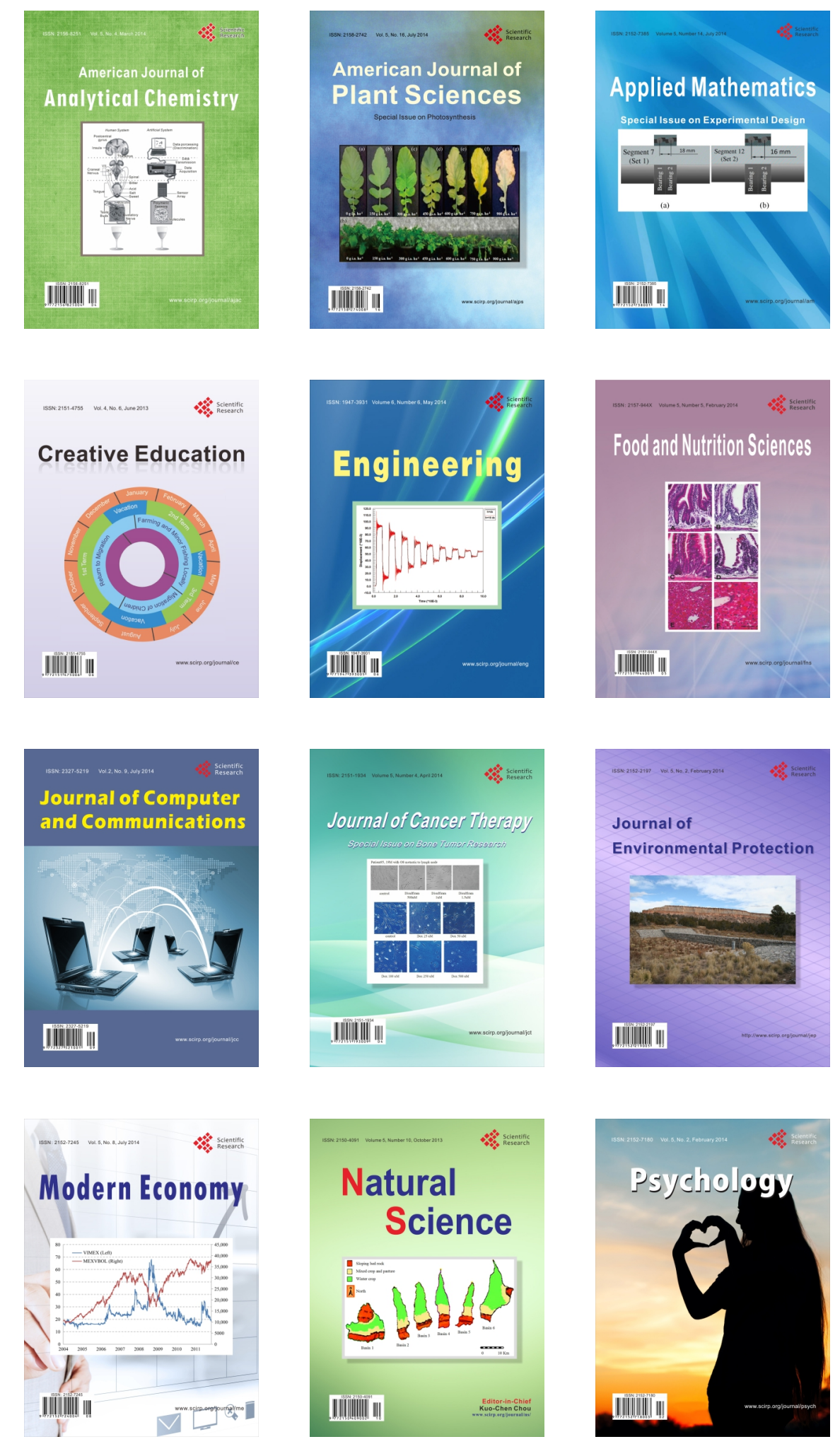